\title{
A DESCRIPTIVE STUDY OF THE OFFER AS FOUND IN AMERICAN MOVIES
}

\begin{abstract}
Musadad
INTISARI

Penawaran adalah salah satu bentuk realisasi tindak tutur. Membuat penawaran dalam bahasa Inggris termasuk salah satu contoh nyata dari pembelajaran komunikatif bahasa Inggris. Oleh karenanya, seseorang tidak seharusnya belajar penawaran dalam bahasa Inggris hanya dari buku-buku tata bahasa Inggris tetapi juga harus dari situasi tertentu yang menggambarkan aspek-aspek kehidupan nyata. Situasi tersebut yang kemudian dikenal sebagai konteks bisa ditampilkan melalui film-film Amerika. Penelitian ini mendapatkan temuan yang menarik terhadap orang-orang yang memanipulasi dan mengolah penawaran-penawaran dalam bahasa Inggris. Secara garis besar, temuan-temuan ini terlihat pada tiga aspek utama yaitu panjang tuturan (rangkaian penawaran), klasifikasi tindak tutur penawaran, dan klasifikasi bagian-bagian penawaran yang paling sering digunakan oleh penutur dalam kaitannya dengan perbedaan umur, tingkat kenal, dan status.
\end{abstract}

Kata Kunci: penawaran, rangkaian penawaran, tindak tutur, konteks, formula semantik

\begin{abstract}
The offer is one form of speech act realizations. Making offer in English belongs to a real example of communicative English learning for it requires practical implementation in some ways. Accordingly, one should not only comprehend the offer in English from what is stated in English grammar books, but also from certain situation providing imaginary life aspects as can be found in the real ones. Such a situation, which is later on called as context, can be displayed through American movies. This study found interesting features in the way the subjects manipulate and manage offers intended to their hearers. The features are mainly noted in three aspects which are utterance length indicating offer (offer-sequence), speech act classification indicating offer, and the most frequently used semantic formulae in accordance with the differences of age, familiarity, and status.
\end{abstract}

Keywords: offer, offer-sequence, speech act, context, semantic formulae

\section{INTRODUCTION}

An electronic medium, a movie has various functions and is watched by people all over the world since it reflects real life, directly or indirectly. The life in the movie seems to be the mirror of life in the real world. It then provides imaginary life aspects as can be found in the real ones. Daily activities, conversation, and characters in movies are commonly found in drama movies. The most obvious characteristic of drama movies is the frequency of its dialogue. They differ from action movies which are full of fighting, wars, clashes, and violence.
Many kinds of utterance (speech acts) can be found in the movie dialogue. One of the speech acts that the characters produce is giving offer. In addition, movies containing more dialogues can be studied from the point of offer view. Meanwhile, drama movies can show the use of language including offer made by characters of different age, familiarity, and status. The semantic formulae produced by the interlocutors in the movies are possible to be used as data source in this study. Therefore, it is very interesting to study what kind of offers they make. 
Generally, this study aims at identifying the linguistic phenomena occurring in the process of communication among characters in American drama movies. However, the more specific objectives are as follows: (1) to describe the most frequently used semantic formulae of offers, (2) to explain the offers made by people of different ages, (3) to explain the offers made by people of different familiarity, and (4) to explain the offers made by people of different status.

This study is limited at analyzing the speech acts of offer in accordance with the differences of age, familiarity, and status. It focuses on the length and classification of offer meaning the types of speech acts that are used together to express the intention of offering.

Essentially, this study is intended to give theoretical and practical contributions. Firstly, this study is expected to contribute to theoretical enrichment. It means that it contributes to the variation and depth regarding pragmatic study in general and speech acts of offer in particular. This research will observe how offer as one of the speech acts is classified and the result of this classification theoretically will be able to show various combination of the offer construction affected by speakers of different age, familiarity, and status. Meanwhile, in terms of practical contribution, this study can enrich the knowledge concerning how to make offer in English. Moreover, this study may be used for various needs for example language teaching, translation, or other communicative functions.

The study of speech acts is concerned with the study of meaning in context. Generally, there are two influential thinkers concerning the speech act theory. They are an English philosopher, Austin, the creature, and an American philosopher John R. Searle, the proponent and the defender (Mey, 1993:110). Austin (1962) says that basically when someone says something he also acts something.
For example, we use language to apologize, to order, to warn, to threaten, to request, and so on. When someone uses words promise, apologize, name, and pronounce, as written by Nadar (2009:11), in the following sentences: I will come on time, I apologize for coming late, and I name this ship Elizabeth, he/she does not merely say those words but also conduct the acts of promise, apologize, and name.

Finnegan defines speech act as actions that are carried out through language (Finnegan, et al., 1992:307). He also divides the speech acts into seven categories:

a. Representatives: speech acts that are representing a state of affairs, e.g. assertions, claims, hypotheses, descriptions, and suggestions.

b. Commissives: speech acts that commit a speaker to a course of actions, e.g. promises, pledges, threats, and vows.

c. Directives: speech acts intended to get the addressee to carry out an action, e.g. commands, requests, challenges, invitations, and entreaties.

d. Declarations: speech acts that bring out the states of affairs, e.g. blessings, firings, baptisms, arrests, marrying, dismiss a case.

e. Expressives: speech acts that indicate the speaker's psychological state or attitude, e.g. greetings, apologies, congratulations, condolences, and thanks-giving.

f. Verdictives: speech acts that make assessments of judgments, e.g. ranking, assessing, and appraising.

By referring to the spech act classification proposed by Finnegan, it can be noted that the offer belong to commissive speech act. Someone giving an offer, directly or indirectly, is committing himself to do an action.

In producing offers, there are some principles that one should realize; one of them is principle of cooperation. This principle is 
necessary in a conversation in order to maintain some information employed by people engaging in a conversation so that they can cooperate to each other to make a cooperative conversation. Grice (1985:45) in Verschueren (1999:32) gives the formulation of the cooperative principle as follows: "make your conversational contribution such as is required, at the stage at which it occurs, by the accepted purpose and the direction of the talk exchange in which you are engaged."

In giving offer, people also have to consider the choice of words they use and the way they express. It means that they should consider principle of politeness. In term of Politeness Principle (PP), Leech (1983:83) makes distinction between ABSOLUTE POLITENESS and RELATIVE POLITENESS where there are some illocutions (e.g. orders) are inherently impolite, and others (e.g. offers) are inherently polite. Therefore, he draws a conclusion that one of the strategies to obtain a scale of politeness is to increase the degree of politeness by using the more indirect illocution. Indirect illocution tends to be more polite because they increase the degree of optionality and because the more indirect an illocution is, the more diminished and tentative its force tend to be (Leech, 1983:108).

\section{RESEARCH METHODOLOGY 2.1 Method of Data Collection}

The data in this research were collected from 15 American drama movies selected from Wikipedia (http://id.wikipedia.org/wiki/ Daftar film Amerika Serikat menurut kategori). The 15 titles, which vary from those released from 1993 to 2005, are as follows: American Beauty (1999), Eternal Sunshine of the Spotless Mind (2004), Wicker Park (2004), Philadelphia (1993), Closer (2004), Sleepless in Seattle (1993), Maid in Manhat$\tan$ (2002), Confessions of a Teenage Drama Queen (2004), Daddy Day Care (2003), The Interpreter (2005), Meet the Parents (2000),
Bruce Almighty (2003), Mean Girls (2004), Ace Ventura 2 - When Nature Calls (1995), and Kate and Leopold (2001).

Since movies are the main data sources, this research emphasizes on the subtitles not the script. As a consequence, the whole stories in every single movie must be watched fully in order to recognize the context. It means that the dialogues and the contexts are elicited by paying attention on the subtitles as well as the story. Therefore, once a statement of offer is recognized, it should be recorded by writing it down along with the time at which it occurs.

\subsection{Method of Data Analysis}

In order to analyze the speech acts attained from the subtitles of those movies, an adapted classification of speech acts used will be used in study. As it is recognized, a speech act is the minimal unit of communication, and a speech acts is a pragmatic unit referring to a stretch of speech with a communicative function. Therefore, an act may comprise several interdependent sub-acts (Searle, 1969:24).

This study adapts a theory on such a category proposed by Beebe, et al. (1990). The coding categories are also helpful in order to make the statistical data. In addition, to facilitate the easier calculation showing tendencies toward utterance-sequence, the researcher needs standard and permanent codes which do not change during the research.

Since it is found many utterances and offer forms which do not correspond to the codes in Beebe's Classification, additional codes are necessary to include. Accordingly, the additional list of the codes MUST be consistent and not change during the study. These mainly include the additional codes for utterances as well as for offers.

It is necessary to code each variable in order to make the analysis easier. In this study, the three coded variables are as follows: difference of age coded by O/SA/Y (Older/Same Age/Younger), difference of familiarity coded 
by U/F (Unfamiliar/Familiar), and difference of status coded $\mathrm{S}>\mathrm{H}, \mathrm{S}=\mathrm{H}, \mathrm{S}<\mathrm{H}(\mathrm{S}=$ Speaker, $\mathrm{H}=$ Hearer).

All offers are then examined and each of the utterances within them is assigned to one of the categories in framework outlined (Beebe's Classification). Then, the coded utterances by each group are analyzed in terms of speech acts classification. The following data is a sample text analysis typical of that used throughout the study.

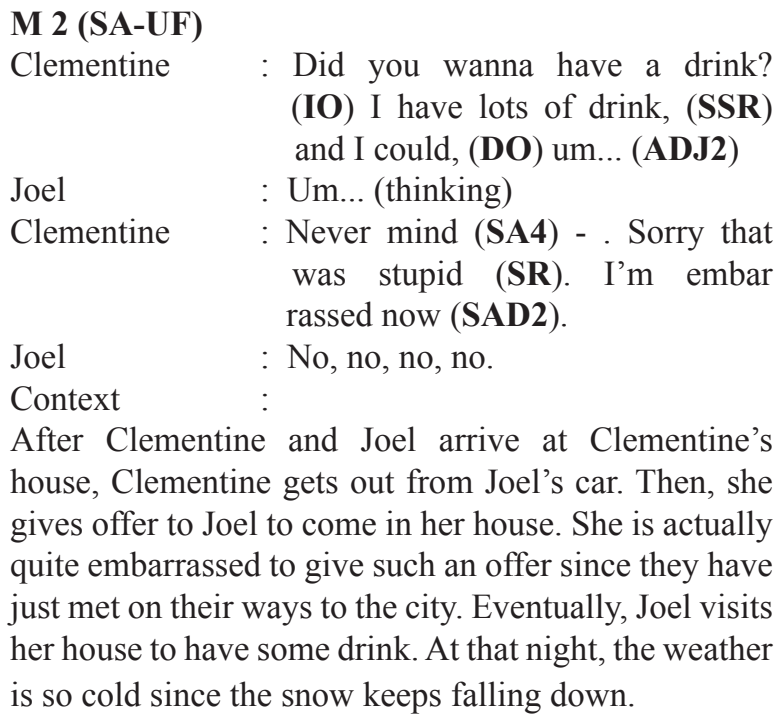

Joel : No, no, no, no.

Context

After Clementine and Joel arrive at Clementine's house, Clementine gets out from Joel's car. Then, she gives offer to Joel to come in her house. She is actually quite embarrassed to give such an offer since they have just met on their ways to the city. Eventually, Joel visits her house to have some drink. At that night, the weather is so cold since the snow keeps falling down.

From the example above, a data containing offer-sequences can be obviously recognized since it consists of some utterances (indicating the offer) and are coded by using Beebe's Classification. The meanings of the coding of the speech acts are presented below.

IO $\rightarrow$ Interrogative Offer

DO $\rightarrow$ Declarative Offer

ADJ2 $\rightarrow$ Pause fillers

SA4 $\rightarrow$ Directive statement

SR $\rightarrow$ Statement of regret
SAD2 $\rightarrow$ Statement of negative feeling

SSR $\rightarrow$ Statement of Specific Reason

As a result, there are 7 utterances as offer-sequence in one statement. Meanwhile, the variable of the speech act can be detected from a code put in the bracket above the dialogue - M 2.2 (SA-UF). The "M 2" means that the dialogue is taken from data in movie number 2. The (SA-UF) means that the offerer is unfamiliar with the receiver and both are about the same ages. This data is to be included as the data analysis in "Same AgeUnfamiliar Relationship."

\subsection{Method of Presenting Data Analysis Results}

The first presentation of data analysis will be that concerning the overall used semantic formulae. Therefore, the overall codes (Beebe and additional codes) will be put in columns of the table. Nevertheless, the table is limited on the 7 highest numbers. Meanwhile, the second presentation is concerned with the overall collected data which are put in series based on three variables as follows: the differences of age, familiarity, and status.

The classification of overall data for each variable is based on the core objectives of the research which are a) the length of utterances indicating offer (offer-sequences) and b) the classification of speech acts indicating offer along with their types. In correlation with those two divisions, each variable is also divided into some sub-variables in order to explain the relationship between the offerer and the receiver. Basically, the basis for grouping sub-variables is depicted in the following table:

Table 1. Classification of combined variable analysis (offerer to receiver)

\begin{tabular}{|l|l|l|l|}
\hline The different level of status & \multicolumn{1}{|c|}{ The familiarity } & The difference of age & The familiarity \\
\hline Higher $(\mathrm{S}>\mathrm{H})$ & Familiar $(\mathrm{F})$ & Older $(\mathrm{O})$ & Familiar $(\mathrm{F})$ \\
\hline Higher $(\mathrm{S}>\mathrm{H})$ & Unfamiliar $(\mathrm{UF})$ & Older $(\mathrm{O})$ & Unfamiliar (UF) \\
\hline The same $(\mathrm{S}=\mathrm{H})$ & Familiar $(\mathrm{F})$ & The same $(\mathrm{SA})$ & Familiar (F) \\
\hline The same $(\mathrm{S}=\mathrm{H})$ & Unfamiliar (UF) & The same (SA) & Unfamiliar (UF) \\
\hline
\end{tabular}




\begin{tabular}{|l|l|l|l|}
\hline Lower $(\mathrm{S}<\mathrm{H})$ & Familiar $(\mathrm{F})$ & Younger $(\mathrm{Y})$ & Familiar $(\mathrm{F})$ \\
\hline Lower $(\mathrm{S}<\mathrm{H})$ & Unfamiliar $(\mathrm{UF})$ & Younger $(\mathrm{Y})$ & Unfamiliar $(\mathrm{UF})$ \\
\hline
\end{tabular}

As illustrated in Table 3, this study emphasis its analysis on two variables (status and age) combined with variable of familiarity. A three-combined variable (age, status, and familiarity) is not included in the analysis since it will be so complicated. Therefore, there are only the combinations of age-familiarity and status-familiarity which are investigated and studied in this study.

\section{FINDINGS AND DISCUSSION}

\subsection{Overall Choice of Semantic Formula}

This section discusses research question no.1 concerning the most frequently used semantic formula by the interlocutors. The forms and contents of semantic formulae found in the 12-combined variables will also be discussed.

Based on Table 3 above, it can be seen that most offer utterances fill in the overall semantic formulae in both Beebe's classification and additional codes. There are several semantic formulae which only get a little number but some get higher. However, the Table shows 7 highest-ranked numbers which are presented on the table below:

Table 2. The most frequently used semantic formulae of the throughout expressions

\begin{tabular}{|c|l|c|}
\hline Rank & \multicolumn{1}{|c|}{ Semantic formulae } & Percentage \\
\hline 1 & Declaratives Offer & $21.37 \%$ \\
\hline 2 & Interrogative Offer & $17.13 \%$ \\
\hline 3 & Statement of Specific Reason & $14.91 \%$ \\
\hline 4 & Statement of Giving Information & $8.46 \%$ \\
\hline 5 & Terms of Address & $8.06 \%$ \\
\hline 6 & Pause Fillers & $5.24 \%$ \\
\hline 7 & Asking for Clarification & $4.83 \%$ \\
\hline
\end{tabular}

As seen in Table 4 displaying the 7 most frequently used semantic formulae, the declaratives offers, e.g., "I've got a job for you, unless you've got other offers," "If you need anything, you can call the precinct or just go downstairs," is the most frequently used ones with $21.37 \%$ while the interrogative offer, e.g., "What do you want me to do?" "Want me to carry you?" is in the 2 nd position. These findings then lead to an understanding that the speakers tend to be polite in delivering their offers. As it is realized in politeness strategy, people tend to apply interrogatives or declaratives to do a Face Threatening Acts (FTA) according to whom they make an interaction.

The two offer forms are then followed by statement of specific reason, statement of giving information, terms of address, pause fillers, and asking for clarification. The presences of statement of specific reason, e.g., "I have some in the fridge, "I just want to help," etc, and statement of giving information like "I'm not selling anything", "My name is Kevin Gnapoor," etc indicate that the offerers tend to employ additional speech acts (called speech act sequence) in forms of specific reasons or extra information in order, e.g., to convince the receivers about what is being offered and to show the offerers' sincerity in giving the offers.

The high number of terms of addresses, such as Mr., Mrs., Gentlemen, and so on, strengthens the offerers' politeness in giving offers. Mentioning people's terms of address in producing utterances frequently occurs on interlocutors having distant relationship, younger speakers, and formal situation.

The high number of pause fillers gives us information that most of offerers seem to be embarrassed, doubtful, or thoughtful about what they are going to offer to the hearers. They tend to say "um..., well, uh..., etc." in the process of giving the offers. This visibly happens once the offerers are not sure with something offered or feel ashamed. Frequently, the pause fillers emerge on the unfamiliar and lower status speakers. 
Lastly, the presence of asking for clarification supports the offerers' hesitancy in giving offers. The utterances like "do you still have time?" or "are you still looking for work? " indicates that the offerers are demanding the clarification about something relating to the receivers' interests before they deliver their offers. Generally the presence of this semantic formula has no tendency towards particular variable (age, status, or familiarity) meaning that it appears naturally without any influence of each variable.

\subsection{Analysis on the Overall Combined Variables}

This section addresses research question no. 2, 3, and 4 concerning the length of utterance and the classification of speech acts indicating offer. Thus, overall analysis will refer to the two concentrations. There are 12 sub-sections discussing each combined variables as explained in the method of presenting the data analysis.

Table 3. Rank and Frequency of the most frequently used semantic formula on 12 combined-variables

\begin{tabular}{|c|c|c|c|c|}
\hline Rank & 1 & 2 & 3 & 4 \\
\hline $\mathrm{O}-\mathrm{F}$ & $\begin{array}{l}\text { Interrogative offer } \\
(20 \%)\end{array}$ & $\begin{array}{l}\text { Statement of specific } \\
\text { reason }(18.18 \%)\end{array}$ & $\begin{array}{l}\text { Declarative offer (16.36 } \\
\%)\end{array}$ & $\begin{array}{l}\text { Asking for clarification } \\
(7.29 \%)\end{array}$ \\
\hline $\mathrm{O}-\mathrm{UF}$ & $\begin{array}{l}\text { Declarative offer } \\
(26.31 \%)\end{array}$ & $\begin{array}{l}\text { Interrogative offer } \\
(21.05 \%)\end{array}$ & $\begin{array}{l}\text { Statement of } \\
\text { convincing }(15.78 \%)\end{array}$ & $\begin{array}{l}\text { Terms of address } \\
(10.52 \%)\end{array}$ \\
\hline $\mathrm{SA}-\mathrm{F}$ & $\begin{array}{l}\text { Declarative offer } \\
(34.09 \%)\end{array}$ & $\begin{array}{l}\text { Interrogative offer } \\
(13.63 \%)\end{array}$ & $\begin{array}{l}\text { Statement of specific } \\
\text { reason }(9.09 \%)\end{array}$ & $\begin{array}{l}\text { Terms of address, } \\
\text { Expression of positive } \\
\text { opinion/feeling }(6.81 \%)\end{array}$ \\
\hline SA - UF & Pause fillers $(25 \%)$ & Declarative offer $(20 \%)$ & $\begin{array}{l}\text { Statement of giving } \\
\text { information }(15 \%)\end{array}$ & $\begin{array}{l}\text { Statement of regret, } \\
\text { Interrogative offer, } \\
\text { Statement of specific } \\
\text { reason }(10 \%)\end{array}$ \\
\hline $\mathrm{Y}-\mathrm{F}$ & $\begin{array}{l}\text { Declarative offer } \\
(26.19 \%)\end{array}$ & $\begin{array}{l}\text { Statement of specific } \\
\text { reason, Interrogative offer } \\
(16.67 \%)\end{array}$ & Terms of address $(12.5 \%)$ & Pause fillers $(8.33 \%)$ \\
\hline $\mathrm{Y}-\mathrm{UF}$ & $\begin{array}{l}\text { Interrogative offer } \\
(27.78 \%)\end{array}$ & $\begin{array}{l}\text { Statement of giving } \\
\text { information }(22.22 \%)\end{array}$ & $\begin{array}{l}\text { Terms of address } \\
(16.67 \%)\end{array}$ & $\begin{array}{l}\text { Expression of positive } \\
\text { opinion/feeling }(11.11 \%)\end{array}$ \\
\hline $\mathrm{S}>\mathrm{H}-\mathrm{F}$ & $\begin{array}{l}\text { Declarative offer } \\
(31.65 \%)\end{array}$ & $\begin{array}{l}\text { Statement of specific } \\
\text { reason }(12.66 \%)\end{array}$ & $\begin{array}{l}\text { Interrogative offer, Terms } \\
\text { of address, Asking for } \\
\text { clarification }(7.59 \%)\end{array}$ & $\begin{array}{l}\text { Statement of giving } \\
\text { information }(6.32 \%)\end{array}$ \\
\hline $\mathrm{S}>\mathrm{H}-\mathrm{UF}$ & $\begin{array}{l}\text { Statement of specific } \\
\text { reason }(26.67 \%)\end{array}$ & $\begin{array}{l}\text { Interrogative offer, } \\
\text { Declarative offer }(20 \%)\end{array}$ & $\begin{array}{l}\text { Terms of address, } \\
\text { Statement of giving } \\
\text { information }(10 \%)\end{array}$ & $\begin{array}{l}\text { Direct statement, Asking } \\
\text { for clarification }(6.67 \%)\end{array}$ \\
\hline $\mathrm{S}=\mathrm{H}-\mathrm{F}$ & $\begin{array}{l}\text { Statement of specific } \\
\text { reason }(27.58 \%)\end{array}$ & $\begin{array}{l}\text { Declarative offer } \\
(22.41 \%)\end{array}$ & $\begin{array}{l}\text { Interrogative offer } \\
(12.06 \%)\end{array}$ & $\begin{array}{l}\text { Statement of giving } \\
\text { information, Asking for } \\
\text { clarification }(8.62 \%)\end{array}$ \\
\hline $\mathrm{S}=\mathrm{H}-\mathrm{UF}$ & $\begin{array}{l}\text { Statement of } \\
\text { giving information } \\
(21.73 \%)\end{array}$ & $\begin{array}{l}\text { Declarative offer } \\
(17.39 \%)\end{array}$ & Pause fillers (13.04\%) & $\begin{array}{l}\text { Interrogative offer, State- } \\
\text { ment of specific reason, } \\
\text { Statement of convincing } \\
(8.69 \%)\end{array}$ \\
\hline $\mathrm{S}<\mathrm{H}-\mathrm{F}$ & $\begin{array}{l}\text { Interrogative offer } \\
(20.27 \%)\end{array}$ & $\begin{array}{l}\text { Declarative offer } \\
(14.86 \%)\end{array}$ & $\begin{array}{l}\text { Statement of specific } \\
\text { reason }(10.81 \%)\end{array}$ & Pause fillers $(8.1 \%)$ \\
\hline $\mathrm{S}<\mathrm{H}-\mathrm{UF}$ & $\begin{array}{l}\text { Interrogative offer } \\
(43.58 \%)\end{array}$ & $\begin{array}{l}\text { Statement of giving infor- } \\
\text { mation }(12.82 \%)\end{array}$ & $\begin{array}{l}\text { Statement of specific } \\
\text { reason }(10.25 \%)\end{array}$ & $\begin{array}{l}\text { Declarative offer, Terms } \\
\text { of address }(7.69 \%)\end{array}$ \\
\hline
\end{tabular}

Example of data analysis on 1 out of 12 combined variables. 
The Offers of Familiar Interlocutors with 1Older Speakers $(\mathrm{O}-\mathrm{F})$

In this analysis, the familiar interlocutors whom the speaker is older than the hearer are involved. Below is the table showing the analysis results:

Table 40. The Overall Semantic Formula of Familiar Interlocutors with Older Speakers

\begin{tabular}{|c|c|c|}
\hline Number of SF & Chosen Semantic Formulae & Form of Offer \\
\hline 1 & Interrogative offer & Interrogative \\
\hline 2 & Interrogative offer - Asking for clarification & Interrogative \\
\hline 2 & Terms of address - Interrogative offer & Interrogative \\
\hline 2 & Terms of address - Declarative offer & Declarative \\
\hline 2 & Terms of address - Declarative offer & Declarative \\
\hline 3 & Pause fillers - Asking for clarification - Interrogative offer & Interrogative \\
\hline 3 & Expressing surprised - Declarative offer - Terms of address & Declarative \\
\hline 4 & $\begin{array}{l}\text { Interrogative offer - Interrogative offer - Asking for } \\
\text { clarification - Statement of giving information }\end{array}$ & Interrogative \\
\hline 4 & $\begin{array}{l}\text { Statement of giving information - Statement of giving } \\
\text { information - Declarative offer - Statement of specific reason }\end{array}$ & Declarative \\
\hline 6 & $\begin{array}{l}\text { Interrogative offer - Terms of address - Statement of specific } \\
\text { reason - Statement of specific reason - Statement of negative } \\
\text { feeling - Statement of specific reason }\end{array}$ & Interrogative \\
\hline \multirow[t]{2}{*}{6} & $\begin{array}{l}\text { Pause fillers - Asking for clarification - Terms of address - } \\
\text { Statement of specific reason - Declarative offer - Declarative } \\
\text { offer }\end{array}$ & Declarative \\
\hline & $\begin{array}{l}\text { Terms of address - Statement of specific reason - Declarative } \\
\text { offer - Asking for agreement - Interrogative offer - Declara- } \\
\text { tives offer }\end{array}$ & $\begin{array}{l}\text { Interrogative }+ \\
\text { Declarative }\end{array}$ \\
\hline 6 & $\begin{array}{l}\text { Statement of specific reason - Statement of specific reason - } \\
\text { Terms of address - Declarative offer - Statement of specific } \\
\text { reason - Statement of specific reason }\end{array}$ & Declarative \\
\hline 11 & $\begin{array}{l}\text { Statement of compliment and expression of appreciation - } \\
\text { Terms of address - Expression of positive opinion/feeling - } \\
\text { Terms of address - Interrogative offer - Pause fillers - State- } \\
\text { ment of warning - Suggestion - Interrogative offer - Terms of } \\
\text { address - Interrogative offer }\end{array}$ & Interrogative \\
\hline
\end{tabular}




\section{Lengths of Utterance Indicating Offer}

As shown in Table 4, there are 6 numbers of semantic formulae found in the overall chosen semantic formula of familiar interlocutors with older speakers. They are 1, 2, 3, 4, 6 , and 11 . The number of declarative forms is much more than the interrogative ones. They are quite the same in numbers they get. There are 8 declarative forms while the interrogative ones get 7 . However, there is still an utterance using the combination of the two forms. It is found in the 6 utterance-length. The nearly obtained balance of the numbers of two offer forms indicates that there is almost no significant difference of offer forms in familiar interlocutors with older speaker.

The various lengths of the offers give us information that different familiarity and age contribute much in the numbers of speech acts made to deliver offers. For example, the 1 utterance-length occurs when the situation is informal. An offer "do you want a sip?" is spoken in a relaxing situation in a living room. It will differ from the 11 utterance-length in which although the situation is a little bit relaxing but it is influenced much by the hearer. From the 11 utterance-length data, it can be recognized that the hearer refuses and ignores the speaker's offers so that the speaker makes more offers to convince his hearer or to show that he is serious about what is being offered.

\section{$>$ Classification of Speech Acts in the Utterances Indicating Offer}

The overall semantic formulae are dominated by interrogative offer $(20 \%)$, statement of specific reason $(18.18 \%)$, declarative offer $(16.36 \%)$, and asking for clarification (7.29\%). The interrogative offer is followed by statement of specific reason meaning that reasons are needed more in giving offers compared to other semantic formulae.

As Table 3 shows, the 2 utterance-length is frequently followed by terms of address so that the offer-sequence is frequently formed by that semantic formula. On the contrary, the 3 length-utterance is more elaborate than 2 utterance-length. It has pause fillers, asking for clarification, expressing surprised, and terms of address. Meanwhile, the 4, 6, and 11 utterance-lengths employ more statement of specific reason and terms of address than other semantic formulae.

Note: The remaining 11 combined variables are analyzed by applying the same analysis method with the above example.

\section{CONCLUSION}

A number of data found in the findings point to different ranks of frequently used semantic formulae. It can be seen that the two offer forms (declarative and interrogative) dominate the ranks in which declarative offer is the first-highest ranked semantic formula and interrogative offer is the second-highest ranked one. These are then followed by statement of specific reason, statement of giving information, terms of address, pause fillers, and asking for clarification. Thus, such a finding leads to a clear conclusion that the English native speakers tend to use declarative (indirect) form rather than interrogative (direct) one in delivering their offers.

The utterance lengths made by people who have different familiarity, age, and status share different frequencies. Even for those who are unfamiliar with the hearers/receivers, the length shows significant differences. People who have either higher status or older age tend to employ shorter utterances. Within the shorter utterances, the speakers tend to give offers in interrogative and declarative forms. Meanwhile, the longer utterances are found in unfamiliar speakers/offerers. Different from the shorter utterances, the longer utterances shows more elaborately used semantic formulae apart from both offer forms. Furthermore, 
the utterance-lengths are usually affected by situation in which the dialogue between the speakers and hearers occurs. Once the dialogues are spoken in a serious situation and are demanding more attention from the hearer, the offer-sequences tend to be longer than those take place in a relaxing or unserious situation.

The classification of speech acts indicating offer also has variedly chosen semantic formulae. The offers are not only dominated by offer forms (interrogative and declarative), but also other semantic formulae including statement of specific reason, statement of giving information, pause fillers, and terms of address. The elaborate offers given to the hearers showing different variables tend to result in different chosen semantic formula. The high number of statement of specific reasons and statement of giving information give us an overview that the speakers produce more utterances to strengthen their offers so that their hearers will perceive that they sincerely give the offers. Meanwhile, the presence of pause fillers indicates that the speakers are a little bit uncertain or doubtful in giving the offers. Moreover, the politeness in giving offers is still able to be detected by paying attention on some number of terms of address in the findings.

\section{BIBLIOGRAPHY}

Austin, J.L. 1962. How to Do Things with Words. Oxford: Oxford University Press.

Finnegan, Edward., et al. 1992. Language: Its Structure and Use. Marrickville: Harcourt Brace Jovanovich Group Ltd.

Grice, H. P. (1975). Logic and conversation. In P. Cole, \& J. Morgan (Eds.). Syntax and Semantics 3: Speech Acts. New York: Academic press

Leech, Geoffrey N. 1983. Principles of Pragmatics. New York: Longman Inc.

Mey, Jacob L. 1993. Pragmatics: An Introduction. Cambridge, Massachusetts: Blackwell Publishers.

Nadar, Franciscus X. 2009. Pragmatik dan Penelitian Pragmatik. Yogyakarta: Graha Ilmu.

Searle, John R. 1969. Speech Acts: An Essay in the Philosophy of Language. Cambridge: Cambridge University Press.

Verschueren, Jeff. 1999. Understanding Pragmatics. London: Arnold.

Wikipedia (http://id.wikipedia.org/wiki/Daftar_film Amerika_Serikat_menurut_kategori) 